\title{
Nigella sativa (Kalonji): A Black Seed of Miracle
}

\author{
Shifali Thakur ${ }^{1}$, Hemlata Kaurav², Gitika Chaudhary ${ }^{3}$ \\ ${ }^{1}$ Junior Research Executive, ${ }^{2}$ Research Associate, ${ }^{3}$ HOD Research and Development, \\ Shuddhi Ayurveda Jeena Sikho Lifecare Pvt. Ltd. Zirakpur, Punjab - 140603, India
}

Corresponding Author: Gitika Chaudhary

\begin{abstract}
It is recommended by the World health organization (WHO) that most of the world's population depends on herbal medicine for their health care. Nigella sativa is commonly known as a Black seed, Black cumin or 'Habbatul Barakah' i.e. an annual herb possessing a wide range of medicinal uses apart from its commercial significance as a spice yielding plant. It has long been used in the folk medicine system of the Arabian Gulf region, Far East Asia, and Europe. Seeds and oils of N. Sativa are the primary medicinal source from ancient times. It is one of the most common herbal plants used worldwide and possesses various chemical constituents such as thymoquinone, thymohydroquinone, dithymoquinone, thymol, nigellicine, carvacrol, nigellicine, nigllimine, nigellidine, and alpha-hederin. There are more than 100 constituents isolated from the plant. These chemical compounds have many pharmacological activities such as antibacterial, antiviral, anti-inflammatory, wound healing effect and also for acne vulgaris, skin cancer, pigmentation and many other cosmeceutical properties. Much scientific research on $N$. sativa has been conducted over the last five decades to investigate chemical and pharmacological properties. In this review, the phytochemicals, pharmacological properties, Ayurvedic properties and folk uses of Nigella sativa are briefly explained.
\end{abstract}

Keywords: Nigella sativa, Kalonji, Antinephrotic, Immunomodulary, Black cumin

\section{INTRODUCTION}

Nigella sativa $\mathrm{L}$. is a small perennial plant long up to 20 to $90 \mathrm{~cm}$ and comes under the Ranunculaceae family ${ }^{[1]}$. It is mostly found in southern Europe, North Africa and Southeast Asia and cultivated in various countries in the world like the Middle Eastern, Mediterranean region, South Europe, India, Pakistan, Syria, Turkey, Saudi Arabia ${ }^{[2,3]}$ The seeds of the plant are considered as a spice and also known as black seed. The seeds have two kinds of oil, fixed and essential and also contains other components such as proteins, alkaloids, and saponins ${ }^{[4,5,6]}$. Thymoquinone is the major compound isolated from the black seed. The compound is isolated from both essential oil and fixed oil. The plant is utilized as a medicine in different cultures

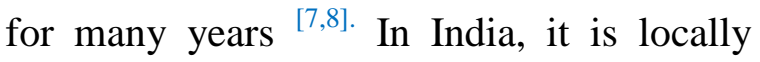
named as 'Kalonji' which has been utilized from ancient times ${ }^{[9] . ~ K a l o n j i ~ s e e d s ~ a r e ~}$ utilized for the treatment of diseases like diarrhea and asthma [10,11]. According to historical literature, $N$. sativa is considered a holy herb of the Middle East. Its seeds are most revered and heal almost everything except death. According to the Unani Tibb system of medicine, the herb is a valuable remedy for several diseases. The famous book of medicine "The cannon of medicine" by Ibn-Sina mentioned that black seeds stimulate the body's energy and helps in recovery from fatigue ${ }^{[12]}$. Nigella sativa is an amazing spice with great literature and religious background. According to the Ayurvedic system of medicine, Nigella sativa is a highly utilized medicinal plant. The seeds of $N$. sativa are suggested with buttermilk to obstinate hiccups and also utilized in loss of appetite, vomiting and dropsy. Many Ayurvedic formulations are 
used to treat different diseases like obesity and dyspnoea. Seeds are also used in mercury poisoning, sore and leprosy [13]. Many chemical compounds are isolated from the $N$. sativa plant-like thymoquinone (30-48\%),

thymohydroquinone, dithymoquinone, p-cymene (7-15\%), carvacrol (6-12\%), 4 cymene, carvacrol, 4 terpineol, $\mathrm{t}$-anethol, sesquiterpene longifolene and a-pinene. These compounds possesses many pharmacological properties. Thymoquinone is the most active phytochemical compound from all of above [14]. Many types of researches have been done on the $N$. sativa plant for their pharmacological activities like antimicrobial, anticancerous, antioxidant, antidiabetic, antinephrotoxic, antiparasitic, antimalarial, antinociceptive effects, antiulcer, anti-histaminic, cardiovascular and many others ${ }^{[15] .}$ The vernacular names and taxonomical classification of Nigella sativa is shown in table no 1 and table no. 2 respectively.

\begin{tabular}{|l|l|}
\multicolumn{2}{|c|}{ Table 1: Vernacular names of Nigella sativa } \\
\hline English & $\begin{array}{l}\text { Fennel Flower, Nutmeg Flower, Raman coriander, } \\
\text { Blaxkseed, black caraway, black sesame }\end{array}$ \\
\hline Hindi/Urdu & Kalaunji/Mangrail \\
\hline Russian & Chernushka, Herbrew, Ketzakh \\
\hline Turkish & Corek out \\
\hline Arabic & Habbat ak-barkah \\
\hline Indonesian & Jintan hitam \\
\hline Bosnian & Curekor \\
\hline French & Nigelle de Crete, toute epice \\
\hline Germany & Schwarzkummel \\
\hline Portuguese & Cominho-negro \\
\hline Spanish & Ajenuz, aranuel \\
\hline Swedish & svartkummin \\
\hline Assamese & Kaljeera, kolajeera \\
\hline Bengali & Kalo jeeray \\
\hline Kannada & Krishna Jeeriage \\
\hline Tamil & Karum, jeerakam \\
\hline
\end{tabular}

Table 2: Taxonomical classification of Nigella sativa

\begin{tabular}{|l|l|}
\hline Taxonomical Rank & Taxon \\
\hline Kingdom & Plantae \\
\hline Division & Magnoliophyta \\
\hline Class & Magnoliopsida \\
\hline Order & Ranunculates \\
\hline Family & Ranunculates \\
\hline Genus & Nigella \\
\hline Species & Nigella sativa \\
\hline Common Name & Black Cumin \\
\hline
\end{tabular}

\section{Botanical Description of Nigella sativa}

Nigella sativa (figure 1) is little prostrate annual herb. The herb is long about $44 \mathrm{~cm}$ to $60 \mathrm{~cm}$. Leaves are divided into two linear segments long up to $3 \mathrm{~cm}$. They are opposite in pair on either side of the stem. The lower leaves are small and petiolate whereas the upper leaves are long. The plant has divided foliage. Flowers are pale blue on solitary long peduncles. It grows terminally on its branches. Seeds are trigonous and black in color. $N$. sativa reproduces with itself and forms a fruit capsule that consists of many white trigonal seeds when the fruit capsule matured. Fruit opens up automatically and the seeds within are exposed to the air becoming black and it is also known as black seeds. Seeds are triangular in shape, black in color and possess a pungent smell. It contains a considerable quantity of oil ${ }^{[16,17]}$

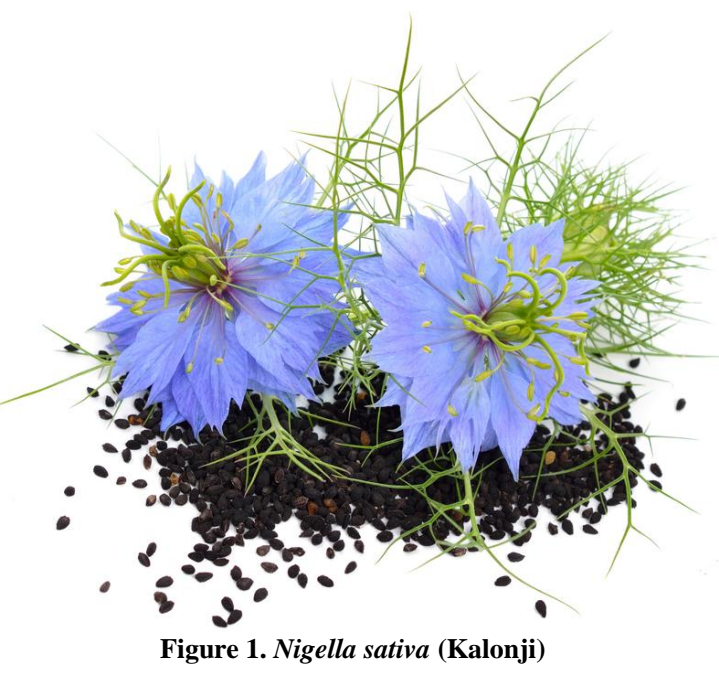

Geographical Distribution: The plant is widely distributed in different areas of the world. It is mainly found in India and Pakistan. The species is grown in Syria, Lebanon, Israel, South Europe and Bangladesh. $N$. sativa is cultivated in the times of winter same as wheat. In India, it is specially grown in Punjab, Himachal Pradesh, Gangetic plains, Bihar, Assam and Maharashtra ${ }^{[18,19]}$

\section{Phytochemical of $N$. sativa}

There is very little research work done on the phytochemicals of $N$. sativa. The seeds of the plant are reported to contain few chemical compounds like 
nigellone, nigellicine, nigellimine, nigellimine-N-oxide, avenasterol-5-ene, avenasterol-7-ene, campesterol, cholesterol, citrostadienol, cycloeucalenol, 24-ethyllophenol, obtusifoliol , sitosterol, stigmastanol, stigmasterol, stigmasterol-7ene, beta-amyrin, butyrospermol, cycloartenol, 24-ethyl-lophenol, gramisterol, lophenol, 243-methyllophenol, obtusifoliol, sitosterol, stigmasterol-7-ene, beta-amyrin,butyrospermol, cycloartenol, 24-methylene-cycloarthanol, taraxerol, tirucallol, 3-O-[ $\beta$-D-xylopyranosyl (1-3)- $\alpha-$ L-rhamnopyranosyl (1-4)- $\quad \beta$-Dglucopyranosyl (1-6) $\beta$-D glucopyranosyl] hederagenin, volatile oil $(0.5-1.6 \%)$, fatty oil (35.6- 41.6\%), oleic acid, esters, esters of unsaturated fatty acids with $\mathrm{C} 15$ and higher terpenoids, esters of dehydrosteraric and linoleic acid, aliphatic alcohol, nigellidine, carvone, d-limonene, cymene, $\alpha, \beta$ unsaturated hydroxyl ketone, steroids, hederagenin glycoside, melanthin, melanthigenin, bitter principle, tannins, resin, protein, reducing sugar, glycosidal saponin, 3-O-[ $\beta$-D-glucopyranoside, cycloart-23-methyl-7,20, 22-triene-3 $\beta, 25$ diol, nigellidine-4-O-sulfite, nigellamines $\mathrm{A} 3, \mathrm{~A} 4, \mathrm{~A} 5, \mathrm{C}$, nigellidine $\mathrm{A} 1, \mathrm{~A} 2, \mathrm{~B} 1$ and B2 $[20,21,22,23,24,25]$

The seed oil of the plant $N$. sativa contains cholesterol, campesterol, stigmasterol, $\beta$-sitosterol, $\alpha$-spinasterol, (+)citronellol, (+)-limonene, p-cymene, citronellyl acetate, carvone, nigellone, arachidic, linolenic, linoleic, myristic,oleic, palmitic, palmitoleic and stearic acids, Fixed oil isolated from the N. sativa species are linoleic acid (55.6\%), oleic acid (23.4\%) and palmitic acid (12.5\%) and volatile oils are trans-anethole (38.3\%), p-cymene $(14.8 \%)$, limonene $(4.3 \%)$ and carvone (4.0\%), 2 -(2-methoxypropyl)-5-methyl-1, 4-benzenediol, thymol and carvacrol. Vanilliac acid are isolated from the root part of the plant $[26,27,28,29,30,31]$.

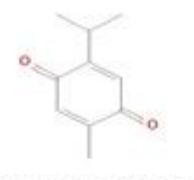

A. Thymoquinone

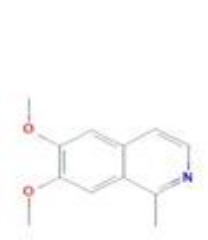

E. Nigellimine

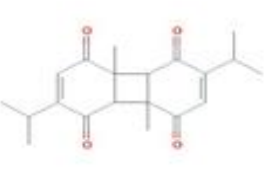

I. Dithymoquinone

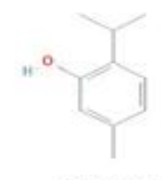

B. Thymol

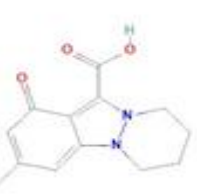

F. Nigellicine

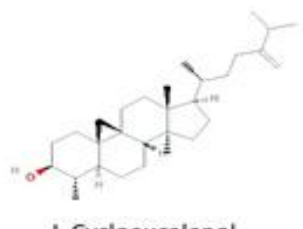

J. Cycloeucalenol

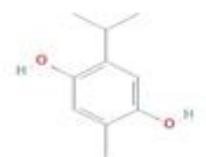

c. Thymohydroquinone

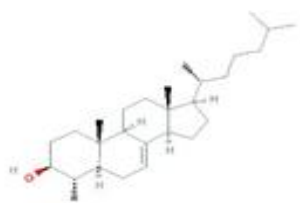

G. Lophenol

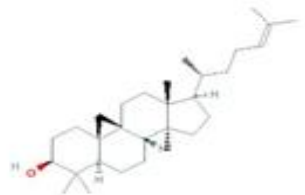

K. Cycloartenol

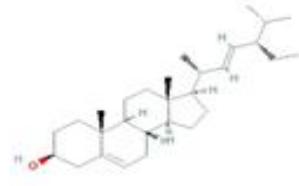

D. Stigmastanol

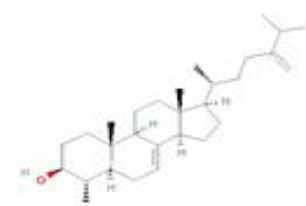

H. Gramisterol

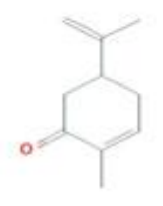

L. Carvone

Figure 2. Chemical structure of some phytochemicals of Nigella sativa (Kalonji)

\section{Folk View}

According to Zohary and Hopf, archaeological evidence about the earliest cultivation of $N$. sativa is still scantly, but they found seeds of this herb in several sites from ancient Egypt including

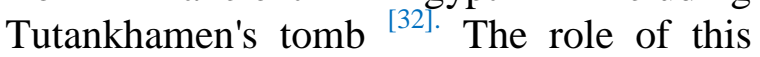
herb in Egypt is still unknown. According to 
the literature, $N$. sativa is a traditional condiment of the old-time and seeds of the herb were extensively used to flavor food. According to the Unani Tibetan system of medicine, $N$. sativa has been considered a valuable remedy in many diseases. The seeds of Nigella sativa stimulate the body's energy and help in recovery from fatigue and dispiritedness. It was also utilized indigestion problems. The seeds have been traditionally utilized for the treatment of asthma, bronchitis, rheumatism, and related inflammation diseases mostly in the Middle East and Southeast Asian countries. It was also used to increase milk production in nursing mothers, to promote digestions and to fight parasitic infections. The seed oil has been utilized to treat skin problems such as eczema and boils. The Arabic quoted this herb as 'Habbatul barakah' means the seed of blessing. Nigella sativa has been utilized by Asians, Africans for medicinal purposes like respiratory health, stomach, intestine, kidney, liver function, circulatory, immune system and for general overall well-being. It is one of the greatest forms of healing medicine in Islam. Prophet Muhammad quoted that the black seed can cure every ailment except death as mentioned in the hadith ${ }^{[33] \text {. }}$

"Narrated Khalid bin Said: We went out and Ghalib bin Abjar was accompanying us. He fell ill on the way and when we arrived at Medina he was still sick. Ibn Abi 'Atiq came to visit him and said to us, "Treat him with black cumin. Take five or seven seeds and crush them (mix the powder with oil) and drop the resulting mixture into both nostrils, for 'Aisha has narrated to me that she heard the Prophet saying, 'This black cumin is healing for all diseases except AsSam.' 'Aisha said, 'What is As-Sam?' He said, 'Death.' " (Bukhari)

Nigella sativa is popular in bread and cakes to detoxifying the body from worms and parasites. The oil contains nigellone that is used for the treatment of asthma, bronchitis and coughs ${ }^{[34,35,36] .}$ The seed oils of the $N$. sativa have a long history of folk usage in Arabian and Indian civilizations. They are sometimes scattered in the folds of woolen fabrics to preserve them from insect damages $[37,38,39,40,41]$.

\section{Ayurvedic View}

Kalonji is a traditional plant used for many years. In the Ayurveda medicine system seeds of $\mathrm{N}$. sativa are effective against many diseases like cough, bronchitis, asthma, chronic headache, migraine, dizziness, chest congestion, dysmenorrheal, obesity, diabetes, paralysis, hemiplegia, back pain, infection, inflammation, rheumatism, hypertension, and gastrointestinal problems such as dyspepsia, flatulence, dysentery, and diarrhea [42]. The plant utilization is also described for the stimulation, diuretic, emmenagogue, lactagogue, anthelmintic and carminative. It is also applied to abscesses, nasal ulcers, orchitis, eczema and swollen joints [43]. The oil of the kalonji seeds is considered to be a local anesthetic ${ }^{[44] . ~ T h e ~}$ Seeds and seed oil the N. sativa are edible and also utilized in traditional dishes. It is used as a flavoring agent in pickles. Rasa Panchak of the N. sativa (kalonji) ${ }^{[45,46]}$ is mentioned in table no. 3 below:

Table 3: Rasa panchak of $N$. sativa (Kalonii)

\begin{tabular}{|l|l|}
\hline Sanskrit/ English & Sanskrit/ English \\
\hline Rasa/ Taste & Katu, Tikta / Pungent, bitter \\
\hline Virya / Potency & Ushana / Hot \\
\hline $\begin{array}{l}\text { Vipaka / Metabolic } \\
\text { property }\end{array}$ & Katu/ Pungent \\
\hline $\begin{array}{l}\text { Guna / Physical property } \\
\text { Laghu, Ruksha, Tikshna / Light, Dry, } \\
\text { sharp }\end{array}$ \\
\hline
\end{tabular}

According to Ayurveda, kalonji increases the pitta dosha (Fire+Water elements), pacifies the Vata dosha (air element) and reduces the Kapha dosha (earth+ water elements). The plant is suitable for Kapha body type and Vata body type and mostly preferred to Vata-Kapha disorders. It is not suitable for Pitta body type and pregnant women. It is helpful in the reduction of the formulation of Ama Dosha (Fire element).

\section{Kalonji Benefits \& Uses}

1. Holitosis (Bad Breath): Ayurveda recommends kalonji use in bad breath. It 
has antihalitosis action. The antihalitosis properties are attributed to its antibacterial and antimicrobial actions in the mouth. For bad breath, take a half teaspoon of kalonji seeds and chew it 2 times a day. It is given for a month for permanent relief from halitosis.

2. Anorexia, Indigestion \& Flatulence: Due to appetite, stimulant, digestive and carminative properties, kalonji helps in anorexia, indigestion and flatulence. It improves the secretion of digestive juice and improves liver function, it improves appetite in cases of anorexia. It prevents the formation of intestinal gas and aids in releasing the wind. So, it helps in flatulence, abdominal distension and abdominal pain occurring due to gas formation. In these diseases, you can chew a half teaspoon of kalonji seeds just before eating foods.

3. Asthma: Kalonji reduces the inflammation of airways and regulates mucus secretion. Some Ayurvedic studies showed kalonji decoction reduces the severity and frequency of wheezing in asthma ${ }^{[47,48] \text {. }}$

4. Dysmenorrhea: In Ayurveda and folk medicine, Kalonji seeds are utilized for improving menstrual flow and alleviating menstrual pain.

5. Galacotogenic Action: Similar to cumin seeds, kalonji seeds also have galactagogic action. It improves the breastmilk supply and inhibits breastmilk abnormalities. It passes through the breastmilk and helps the baby to improve digestion. But in some cases, it can also cause constipation in babies.

\section{Ayurvedic Formulation of Kalonji}

Anupam: Mostly given in Kapha disorder.

\section{Modern View}

There are many issues which is faced by the Global herbal drug industry in today's scenario mostly the practice of making these drugs adulterated. This is the major reason why people lost faith in these herbal drugs nowadays $[49,50,51,52,53,54]$. In today's time, intentional adulteration is practiced in many different ways like by substituting standard commercial variety, by substituting superficially similar but inferior drugs, by substituting artificially manufactured drugs, the substitution of exhausted drugs and by substituting toxic materials. Adulteration can be either intentional or unintentional. These adulteration processes ultimately degrade the quality of the original drugs. The herbal plant vendors use these adulteration techniques so smartly that these remain undetectable until and unless examination on a microscopic level and chemical level are implied $[55,56,57]$. The major disadvantages associated with adulteration are deterioration and degradation of drugs. Adulteration also increases the cost of drugs and produces adverse effects instead of showing actual biological affect ${ }^{[58] \text {. The }}$ traditional herbal drugs and their formulations are associated with negligible toxicity and are free from any kind of adulteration. Traditional Ayurvedic herbal formulations of Kalonji plants are associated with a wide range of medicinal properties too which cures a variety of ailments without causing any severe harm to the human body. Health risks are usually associated with the modern adulterated drugs. For instance, the modern anti-obesity drugs have side effects associated with them whereas the anti-obesity activity of Nigella sativa is well demonstrated by many studies where the least toxicity and adverse effects were observed [59]. The kalonji oil has immune-modulatory activities and has a good effect on diverse conditions from deficiencies of the immune system. So, pharmaceutical industries produced kalonji seeds oils and distributed them worldwide. There are many unsaturated fatty acids isolated from the kalonji seeds which are very useful for the well-functioning immune system. Many scientific studies have been reported that the black seed oil of Nigella sativa possesses immune-modularly properties because it contains at least $60 \%$ 
of the daily need for unsaturated fatty acids. Some of the unsaturated fatty acids cannot be formed by the human body so it has to be taken externally. Pure black seed oil is a very important product in naturopathy. It is utilized by the herbal industry as a nutritional supplement. A teaspoon of black seed oil mixed with yogurt is given to the children from the age of 4 years for a healthy dietary supplement.

\section{Reported Therapeutic Studies of Nigella sativa}

Various studies have been conducted on this plant to know its pharmaceutical and therapeutic uses. Large-scale clinical studies are still needed to prove the clinical efficacy of this herb, especially in skin diseases, immunomodulatory disorders and cancers.

1. Anti-bacterial Activity: Many studies have been reported the antibacterial activity of $N$. sativa. Thymoquinone is the major chemical constituent isolated from this plant. It was found to have antibacterial activity against most bacteria especially in Gram-positive cocci type such as staphylococcus aureus and staphylococcus epidermidis ${ }^{[60,61,62,63] \text {. }}$

2. Antiviral activity: A few recent studies have been done on the antiviral effect of Nigella sativa. A study was held in 2013 which showed significant results about the effect of $N$. sativa oil against hepatitis $\mathrm{C}$ virus (HCV). A clinical study was done on 30 patients with $\mathrm{HCV}$ who were not eligible for IFN/ribavirin therapy. $450 \mathrm{mg}$ of $N$. sativa oil in capsular dosage form were administered orally 3 times daily. After 3 months, a reduction in overall viral counts and improved oxidative stress was noted, clinical condition and glycaemic control in a diabetic patient ${ }^{[64] \text {. }}$

3. Antifungal Activities: From the reported studies it is clear that Nigella sativa possesses antiviral activity against most pathogenic fungi [65]. Thymoquinone was examined for antifungal activity against most fungal strains ${ }^{[66] .}$ A comparative study was reported that the antifungal activity of Nigella sativa was more potent than Amphotericin B drug (an antifungal drug). One more study reported the antifungal activity of $N$. sativa. The methanolic and ethanolic extract of the seeds of $N$. sativa was examined on different pathogenic fungal strains. These strains were Aspergillus, Candida, Cryptococcus and Issatchenkia species. The decoction was prepared by the cold maceration technique and assessed by "The National Committee of Clinical Laboratory Science" (NCCLS) method. It was found that methanolic extract of the plant showed major inhibition of fungal growth against Candida parapsilosis and Issatchenkia Orientalis and ethanolic extract showed significant inhibition against Issatchenkia orientali respectively ${ }^{[67] .}$

In another study, the essential oil and various extracts of $N$. sativa were evaluated against Trichophyton mentagrophytes, Microsporum canis and microsporun gypseum as dermatophyte fungal strains. The antifungal activity of $\mathrm{N}$. sativa was studied by the disk diffusion method. The result showed potent antifungal effect on $T$. mentagrophytes, $M$. canis and M. gypseum ${ }^{[68] .}$

In another study, it was concluded that C. cyminum, Z. clinopodioides and $N$. sativa oils possess antifungal properties. The result showed inhibition in the growth of A. fumigatus and A. flavus [69].

Some researchers reported various treatments of fungal infection by using natural products. $N$. sativa was also reported

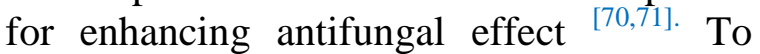
evaluate the anti-fungal activity a micro well dilution assay was performed against three human pathogenic fungal strains that are Aspergillus flavus, Aspergillus niger, Candida albicans and four bacteria i.e. Escherichia coli, Staphylococcus sp., Pseudomonas syringae and Bacillus subtilis. It was found that the methanolic extract of N. sativa shows maximum inhibitory potential against all the test fungi and bacteria ${ }^{[72] .}$ 
4. Antiparasitic Activity: A study was conducted to evaluate that methanolic extract of N.sativa possesses the antiparasitic activity. Extract was tested on Plasmodium-infected mice to evaluate the antiparasitic activity of $N$. sativa. The result showed an excellent suppression up to $94 \%$, $\mathrm{P}<0.05$ compared with chloroquine. The antimalarial activity was found in the mice because of the antioxidant effect of the extract of $N$. sativa ${ }^{[73,74] \text {. }}$

$N$. sativa oil possesses other activities against cestodes and nematodes actions ${ }^{[75,76]}$. A recent study evaluated that oil of N. sativa has an excellent effect in reducing the overall number of Schistosoma mansoni worms in the liver and minimizing the total number of ova that was found in both the liver and intestine ${ }^{[77,78,79]}$.

From the reported studies it was evaluated that $N$. sativa oil and garlic extract were possessed antischistosomal and antioxidant activity. The extract was administered to infected mice. The result showed improvement in hematological, biochemical and antioxidant capacity of schistosomiasis mice compared to the

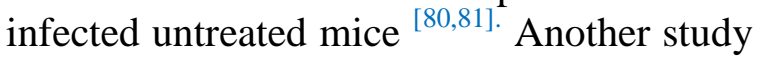
was conducted on $\mathrm{N}$. sativa oil and thymoquinone to evaluate their effectiveness against Sch. mansoni in infected mice. Results showed a reduction in chromosomal abnormalities, especially in chromosomes 2 and 6 , and some in chromosomes 13 and 14 when compared with the control group ${ }^{\text {[82]. }}$

One more study was conducted to know the value of $N$. sativa seeds against various parasites such as Sch. mansoni, mirachidia, cercariae, and adult worms. The beneficial results were found against all these parasites and even in their eggs. Seeds possess antioxidative properties against adult worms which inhibited the activities of some enzymes of glucose metabolism. After few days these enzymes were damaged and parasites was found to be weaker and killed later on ${ }^{[83,84] \text {. }}$
4. Wound Healing Properties: Thymoquinone is the chemical constituent that prevents oxidative injury and membrane lipid peroxidation in tissues. These effects recommended the wound healing application of Nigella sativa ${ }^{[85,86]}$. A study was conducted on the wound model rats to examine the wound healing effect of $N$. sativa plant. The result has shown that it increases the wound healing process by unknown mechanism compared to silver sulfadiazine ${ }^{[87]}$

Another study was reported that hexanic extract of $N$. sativa seeds has good activity on increasing collagen formation and increasing the rate of epithelialization. In the study, hexanic extract was applied topically to examine the healing efficiency of seeds oil on the second-degree burn wound models in rats. The animal models were divided into three groups of six for every group. Silver sulfadiazine was applied as an antiseptic standard drug. The result showed $81.20 \%$ reduction in the wound area which was more than the control group. The study showed complete regeneration of epidermis on the day 12 in the rat model ${ }^{[88]}$.

Abu-Al-Basal et al. investigated that ether extract of $N$. sativa seed possesses wound healing properties. Male BALB/c mice models were infected with $100 \mathrm{microL}$ of staphylococcal aureus suspension at a dose of 10 colony-forming units in the mouse shaved mild dorsal skin. Results showed improvement in the healing process by decreasing the total and absolute white blood cell count, reducing tissue damage and decreasing bacterial expansion ${ }^{[89] .}$

The in vitro study was conducted using a human gingival fibroblast monolayer. Aqueous extracts were evaluated for DPPH scavenging activity and the effect on HGF proliferation was determined. The result showed an increase in the rate of proliferation and closure activity was observed after using the oil ${ }^{[90] \text {. }}$

\section{Anti-inflammatory}

5.1 Psoriasis: The ethanolic extract of Nigella sativa seeds was evaluated for 
antipsoriatic activity. The screening of extract was done by using a mouse tail model for psoriasis. The result showed an increase in relative epidermal thickness when compared with the control group ${ }^{\text {[91]. }}$

Ahmed et al., investigated the ethanolic extract of $N$. sativa to evaluate the antipsoriatic effect. Seed oil was applied in two dosage forms like ointment and oral form. Sixty patients with mild to moderate plaque and palmoplantar psoriasis were selected for this study. The result showed that an oral dose of Nigella sativa produced a good response in patients and possesses antipsoriatic effect ${ }^{[92]}$.

5.2 Acne Vulgaris: It is one of the most widespread infections in human. Many scientific studies have been done and observed that the effect of Nigella sativa oil against acne vulgaris. Hadi and Ashok examined in their study that using $20 \%$ of $N$. sativa oil extract in the lotion formulation has better efficacy. 62 patients who has acne were selected for the study. Results showed Nigella sativa has less harmful than benzoyl peroxide lotion (the lotion used for mild to middle stage of acne vulgaris) ${ }^{[93]}$. Another study was conducted to examine Nigella sativa oil antibiotic effect in comparison with the standard drug amoxicillin. The gel was formulated from the oil using carbopol 940. This formulation was used as a therapy and a good result were obtained. However, Nigella sativa is a good herbal plant used for the treatment of skin that causes infection, irritation, rashes, dermatitis, acne and psoriasis.

\section{Skin Pigmentation}

6.1 Vitiligo: Nigella sativa oil is very effective for the treatment of various types of skin diseases such as vitiligo. The research was focused on the Nigella sativa oil efficiency against vitiligo. The research was held in patients suffering from vitiligo disorder. The scientist suggested putting fish oil and Nigella sativa oil as a therapy. The results showed a decrease in the lesion size and proved to be effective for vitiligo ${ }^{\text {[94]. }}$
Another study observed that Nigella sativa has the power to spread melanin within the skin. The lyophilized seed extract of Nigella sativa was evaluated in the isolated melanophores of the wall lizard to know the mechanism of skin darkening at the cellular level. The study showed the mechanism of action that increased the intensity of melanin by increasing the sensitivity of cholinergic receptors inside the melanopsin. Melanopsin is the external part of lizard ${ }^{[95] .}$ It was also observed that thymoquinone is beneficial for decreasing skin pigmentation and vitiligo.

7. Antioxidant activity: Many in-vivo and in-vitro studies have been conducted with Nigella sativa extracts to evaluate the antioxidant property. It was found that Nigella sativa and its derivatives possessed potential radical scavenging and inhibitory effects on oxidative stress ${ }^{966,97,98,99] .}$. Cherif et al., investigated the effect of dietary Nigella sativa seeds on meat fatty acids and evaluated oxidative activity. Twenty-eight Barbarine male lambs were selected for the study. The diet was given in two different feeding systems i.e. higher or low concentration. It was observed in the end that Thiobarbituric acid reactive substances (TBARS) were lower in the meat of lambs receiving NSS compared to the meat of lambs ${ }^{[100]}$.

8. Anti-cancer Activity: Several studies have been conducted to examine the anticancer effect of Nigella sativa. The extract was tested in cancer cell-derived from mice. The result showed chemopreventive potential found in the thymoquinone [101,102,103]. Khalife et al., investigated that thymoquinone induced apoptosis through p53-independently with p21 and arrested cell-cycle $S$ phase in human colon cancer cells. The active compound showed anticancer effects towards many cancer cell lines including MCF-7/Topo breast carcinoma cells and also decline regulator of NF-B and MMP-9 in Panc- 1 cells and bcl-2 in gastric cancer 
cells [104]. Ahmed at el., observed that a number of derivatives of thymoquinone like 6-menthoxybutyryl, 6-hencosahexanyl conjugate, 4-acylhydrazones and 6-alkyl are also potent to act against various cancer lines ${ }^{[105] .}$ Periasamy et al., suggested that the Nanoemulsion of Nigella oil caused cell membrane blebbing, cytoplasmic vacuolation, marginalization of chromatin and fragmentation of the nucleus in MCF-7 cells ${ }^{[106,107,108,109,110] \text {. }}$

9. Anti-Diabetic Effect: As per the study, the extract of Nigella sativa has potent antidiabetic potential. Thymoquinone was injected in diabetic mice. The result showed a reduction in blood glucose level with augmentation of insulin level and C-peptide

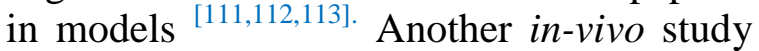
was conducted in the mice to evaluate the antidiabetic activity. The aqueous extract of Nigella sativa was administered daily in the models by gavage. It was found that extract significantly reduced the glycemia, TG, Tcholesterol, LDL-c and TBARS and possessed antihyperglycemic, antihyperlipidemic and antioxidant effect [114].

10. Effect on Nervous system: As per the study, the methanolic extract of Nigella sativa has antidepressant and analgesic property $[115,116]$ and which was demonstrated by a study conducted on rat models. It was found that methanolic extract significantly increased the serotonin and reduced hydroxyindole acetic acid level in the rat brain ${ }^{[117] \text {. }}$

11. Nephroprotective activity: As per the study, Nigella sativa in combination with ascorbic acid have a nephroprotective activity. The decoction was injected into the rabbits. It was found that decoction produced a nephroprotective effect by lowering serum creatinine, blood urea nitrogen and antioxidant activity ${ }^{[118,119] \text {. }}$

12. Effects on pulmonary system: As per the study, the activity of nigellone and thymoquinone was demonstrated by an invivo study carried out on 63 adult male rats. Models were divided into nine groups. The administration of Nigella sativa was found to be very effective and prevent Formaldehyde-induced apoptosis and epithelial damage ${ }^{[120] \text {. }}$

13. Effects on Reproductive system: A study was conducted on Iranian infertile men with criteria of abnormal sperm count. The patient was prescribed Nigella sativa oil for 2 months. After 2 months it was concluded that daily intake of $5 \mathrm{ml}$ Nigella sativa oil improves abnormal semen quality in infertile men without causing any adverse effects ${ }^{[121,122]}$

The activity of Nigella sativa was demonstrated by in-vivo study carried out on a polycystic ovary rat model. Thymoquinone was found to be a potential remedy for balancing the hormonal level in the PCO rat ${ }^{[123] \text {. }}$

Another study conducted in thirty male Wistar rats to investigate the adverse reproductive effects. The models were dosed with acetamiprid and Nigella sativa oil in combination with gavage for 45 days. The result showed stimulation in spermatogenesis and significantly increases the spermatids numbers and the weight of seminal vesicles ${ }^{[124]}$.

\section{Toxicity of the Nigella sativa and its derivates}

From the reported studies it was found that toxicity of fixed oil of $N$. sativa in mice after i.p. and p.o. administration that the $\mathrm{LD}_{50}$ for thymoquinone was 89.7-119.7 $\mathrm{mg} / \mathrm{kg}$ and $647.1-1094.8 \mathrm{mg} / \mathrm{kg}$ respectively. It was found to be $45.6-69.4 \mathrm{mg} / \mathrm{kg}$ and $469.8-1118.8 \mathrm{mg} / \mathrm{kg}$ in the rat after the i.p. and p.o. administered respectively ${ }^{[20]}$.

\section{CONCLUSION}

Medicinal plants have been played a vital role in maintaining the health of the community since ancient times. Nigella sativa (kalonji) is one the most commonly used medicinal herbs in various systems of 
medicine in the folk system, Ayurveda, Siddha and Yunani. This herb is associated with some significant therapeutic actions. It is utilized in the treatment of several diseases. As per the data of reported studies, thymoquinone is considered an active constituent with various biological properties like wound healing, anti-diabetic, anti-inflammatory,

antidepressant, antidiabetic, antibacterial, anti-viral, antifungals etc. Many clinical studies are suggesting that Nigella sativa possessed a wide range of benefits in skin disorders.

\section{Acknowledgement: None}

\section{Conflict of Interest: None}

\section{Source of Funding: None}

\section{Ethical Approval: Not Applicable}

\section{REFERENCES}

1. Ahmad A, Al-Abbasi FA, Sadath S, Ali SS, Abuzinadah MF, Alhadrami HA, Mohammad Alghamdi AA, Aseeri AH, Khan SA, Husain A (2018) Ameliorative efect of camel's milk and Nigella Sativa oil against thioacetamide-induced hepatorenal damage in rats. Pharmacogn Mag 14:27-35

2. Zohary D, Hopf M, and Weiss E, Domestication of Plants in the Old World: The Origin and Spread of Domesticated Plants in Southwest Asia, Europe, and the Mediterranean Basin, Oxford University Press on Demand, 2012.

3. Tahan $M$ and Bayram I. "Effect of using black cumin (Nigella sativa) and parsley (Petroselinum crispum) in laying quail diets on egg yield, egg quality and hatchability," Archiva zootechnica, vol. 14, no. 4, pp. 3944, 2011.

4. Ahmad A. Husain A, Mujeeb M et al., "A review on therapeutic potential of Nigella sativa: a miracle herb," Asian Pacific Journal of Tropical Biomedicine, vol. 3, no. 5, pp. 337-352, 2013.

5. Mathur ML, Gaur J, Sharma R et al., "Antidiabetic properties of a spice plant Nigella sativa," Journal of Endocrinology and Metabolism, vol. 1, no. 1, pp. 1-8, 2011.
6. Javed S, Shahid A, Haider MS et al., "Nutritional, phytochemical potential and pharmacological evaluation of Nigella Sativa (Kalonji) and Trachyspermum Ammi (Ajwain)," Journal of Medicinal Plants Research, vol. 6, no. 5, pp. 768-775, 2012.

7. Ali BH and Blunden G, "Pharmacological and toxicological properties of Nigella sativa," Phytotherapy Research, vol. 17, no. 4, pp. 299-305, 2003.

8. Saad B, Azaizeh H. "Tradition and perspectives of Arab herbal medicine: a review," Evidence-Based Complementary and Alternative Medicine, vol. 2, no. 4, pp. 475-479, 2005.

9. Gilani AH, Aziz N, Khurram IM, Chaudhary KS, Iqbal A. Bronchodilator, spasmolytic and calcium antagonist activities of Nigella sativa seeds (Kalonji): a traditional herbal product with multiple medicinal uses. Journal of Pakistan Medical Association. 2001;51(3):115.

10. Benhaddou-Andaloussi A, Martineau L, Vuong T, Meddah B, Madiraju P, Settaf A, Haddad PS. The in vivo antidiabetic activity of Nigella sativa is mediated through activation of the AMPK pathway and increased muscle Glut4 content. EvidenceBased Complementary and Alternative Medicine. 2011 Jan 1;2011.

11. Ghaznavi KM. Tibbe-e-Nabvi aur Jadid Science, Al-Faisal Nasheeran wa Tajeera-eKutab. Urdu Bazar Lahore, Pakistan. 1991. 1:228-236

12. Chevallier A. Encyclopedia of medicinal plants. New York, NY: DK Publishing. 1996. p. 237.

13. Ahmad Z, Gafoor A, Aslam M (2004). Nigella sativa - A potential commodity in crop diversification traditionally used in health care. Project on Introduction of Medicinal herb and species as crop. Ministry of food, agriculture and livestock, Pakistan

14. Badary, O.A., Al-Shabanah, O.A., Nagi, M.N., Al-Rikabi, A.C., Elmazar, M.M.: Eur. J. Cancer Prev, 8 (5):435-440 (1999).

15. Tembhurne SV, Feroz S, More $\mathrm{BH}$, Sakarkar DM. A review on therapeutic potential of Nigella sativa (kalonji) seeds. Journal of medicinal plants research. 2014 Jan 17;8(3):167-77.

16. Chevallier A. Encyclopedia of medicinal plants. New York, NY: DK Publishing. 1996. p. 237. 
17. Varghese E. SVD “Applied Ethnobotany- A case study among the Kharias of Central India", Deep Publications, New Delhi, (1996)

18. Paarakh, P. M. 2010. Nigella sativa Linn.- A comprehensive review. Indian J. Nat. Prod. 1: 409- 429.

19. Naz, H. 2011. Nigella sativa: the miraculous herb. Pak. J. Biochem. Mol. Biol. 44: 44-48.

20. Rastogi RP, Mehrotra BN. BN Compendium of Indian Medicinal plants Central DrugResearch Institute Lucknow \& NISC. New Delhi. 1993;4:1.

21. Sharma PC, Yelne MB and Dennis TJ, Database on Medicinal Plants used in Ayurveda, vol. 6 , CCRAS, New Delhi , 2005 , 420-440.

22. Rastogi RP, Mehrotra BN. BN Compendium of Indian Medicinal Plants, Reprinted edn., Vol. 4, CSIR . New Delhi. 1993;4:1.

23. Rastogi RP, Mehrotra BN. BN Compendium of Indian Medicinal Plants, Reprinted edn., Vol. 5, CSIR . New Delhi. 1993;4:1.

24. Atta-Ur Rahman, Nigellidine a new indazole alkaloid from the seed of Nigella sativa, Tetrahedron Lett 1995, 36(12), 19931994.

25. Ali Z, Ferreira D, Carvalho P, Avery MA and Khan IA, Nigellidine-4-O-sulfite, the first sulphated indazole-type alkaloid from the seeds of Nigella sativa, J nat prod. 2008, 71(6), 1111,1112.

26. Morikawa T, Xu F, Ninomiya K, Matsuda $H$ and Yoshikawa M, Nigellamines A3, A4, $\mathrm{A} 5$, and $\mathrm{C}$, new dolabellane-type diterpene alkoloiads, with lipid metabolism-promoting activities from the Egyptian medicinal food black cumin, chem pharm bull, 2004, 52(4) 494-497.

27. Morikawa T, Xu F, Kashima Y, Matsuda H, Ninomiya $\mathrm{K}$ and Yoshikawa $M$, Novel dolabellane-type diterpene alkaloids with lipid metabolism promoting activities from the seeds of nigella sativa, Org Lett, 2004, 6(6), 869-872.

28. Rastogi RP, Mehrotra BN. BN Compendium of Indian Medicinal Plants, Reprinted edn., Vol. 3, CSIR . New Delhi. 1993;452-453.

29. Nickavar B, Majab F, Javidnia K and Amoli MA. Chemical composition of the fixed and volatile oils of Nigella sativa L. from Iran, Z Naturforsch C, 2003, 58 (9-10), 639-631.
30. Enomoto S, Asano R, Iwahori Y, Nauri T, Okada Y, Singab AN and Okuyama T, Hemanological studies on Black cumin oil from seeds of Nigella sativa Linn. Biol pharma Bull, 2011, 24(3), 307-310.

31. Bourgou S, Ksouri R, Bellila A, Skandrani I, Falleh $\mathrm{H}$ and Marzouk B, Phenolic composition and biological activities of Tunisian Nigella sativa L. shoots and roots, C R Biol, 2008, 331 (1), 48-55.

32. Daniel Zohary and Maria Hopf, Domestication of plants in the Old World, third edition (Oxford: University Press, 2000), p. 206

33. Akhtar, M.S. \& Rifaat, S. 1991. Field trial of Saussurea lappa roots against nematodes and Nigella sativa seeds against cestodes in children. Journal of the Pakistan Medical Association 41: 185-187.

34. Korshom M., Moghney, A.A. \& Mandour, A. 1998. Biochemical and parasitological evaluation of Nigella sativa against ruminant fluke (Paramphistomum) in sheep as compared with trematocide "Hapadex". Assiut. Vaternary Med. J. 39 (78): 238-244.

35. Azza, M. M., Nadia, M. M. \& Sohair, S. M. 2005. Sativa seeds against Schistosoma mansoni different stages. Mem. Inst. Oswaldo. Cruz. Rio de Janeiro 100(2): 205211.

36. Abdulelah H.A.A. \& Zainal-Abidin B.A.H. 2007. In vivo anti-malarial tests of Nigella sativa (black seed) different extracts. American Journal of Pharmacology and Toxicology 2 (2): 46-50, 2007.

37. Dwivedi, S. N., Dwivedi, Sangeeta \& Patel, P. C. "Medicinal Plants used by the tribals and rural people of Satna district, Madhya Pradesh for the treatment of gastrointestinal disease and disorders", Nat. Pro. Rad. (2006), 5(1): 60-63. 10.

38. Dwivedi, Sumeet; Shrivastava, Satyaendra; Dubey, Darshan; Kapoor, Shweta \& Jain, Sanjay "Status and conservation strategies of herbal oral contraceptives", Planta Indica, (2007)3(1): 5- 7. 11.

39. Kurion, J.C. "Plants that heals", 5th ed. Pune, Oriental watchman publishing house, (2003).

40. Khare, C.P. "Encyclopedia of Indian Medicinal Plants", Springes-Verlag Berlin Heidelberg, New York, (2004).

41. Sinha, R. K. "Tools of investigation. In Ethnobotany: The Renaissaance of 
Traditional Herbal Medicine", INA Shree publication, Jaipur, (1998)

42. Forouzanfar F, Bazzaz BS, Hosseinzadeh H. Black cumin (Nigella sativa) and its constituent (thymoquinone): a review on antimicrobial effects. Iranian journal of basic medical sciences. 2014 Dec;17(12):929.

43. Namazi N, Larijani B, Ayati MH, Abdollahi M. The effects of Nigella sativa L. on obesity: A systematic review and metaanalysis. Journal of ethnopharmacology. 2018 Jun 12;219:173-81.

44. Mousavi SM, Sheikhi A, Varkaneh HK, Zarezadeh M, Rahmani J, Milajerdi A. Effect of Nigella sativa supplementation on obesity indices: A systematic review and meta-analysis of randomized controlled trials. Complementary therapies in medicine. 2018 Jun 1;38:48-57.

45. Sharma P.V. DravyagunaVijnana. Chaukambha Bharti Academy, Varanasi. 2019.

46. Mudgal D. DravyagunVijnana. Ayurvedic Sanskrit Hindi Pustak Bhandar. 2019.

47. Hosseinzadeh H, Eskandari M, Ziaee $T$. Antitussive effect of thymoquinone, a constituent of Nigella sativa seeds, in guinea pigs. Pharmacologyonline. 2008;2:480-4.

48. Boskabady MH, Javan H, Sajady M, Rakhshandeh $\mathrm{H}$. The possible prophylactic effect of Nigella sativa seed extract in asthmatic patients. Fundamental \& clinical pharmacology. 2007 Oct;21(5):559-66.

49. Tewari NN. Some crude drugs: source, substitute and adulterant with special reference to KTM crude drug market. Sachitra Ayurved. 1991.

50. Shukla P, Pawar RM. OA01. 22. Quality aspect and variability observed in physicochemical characteristics and mineral content of ayurvedic herbo mineral formulations from Indian market. Ancient Science of Life. 2012.

51. Sunita G. Substitute and adulterant plants. Substitute and adulterant plants.1992.

52. Uniyal MR, Joshi GC. Historical view of the basic principles of the identification of controversial drugs, problems and suggestions. Sachitra Ayurved. 1993.

53. Saraswathy A. Adulterants and substitutes in Ayurveda. Sachitra Ayurved. 2001.

54. Gupta AK. Quality standards of Indian medicinal plants. Volume 1. Quality standards of Indian medicinal plants. Volume 1.2003.

55. Monika, Kaushal K. Adulteration in Ayurvedic Raw Herbs. International Journal of Science and Research. 2015.

56. Afaq SH. A comparative introduction of the Unani and Tibetan medical traditions. Ayur Vijnana. 1999.

57. Mitra SK, Kannan R. A note on unintentional adulterations in Ayurvedic herbs. Ethnobotanical Leaflets. 2007.

58. More DB, Giradkar PS. Herbal Drug Adulteration: A Hindrance to the Development of Ayurveda Medicine.

59. Tewari NN. Some crude drugs: source, substitute and adulterant with special reference to KTM crude drug market. Sachitra Ayurved. 1991;44(4):284-90.

60. Emeka LB, Emeka PM, Khan TM. Antimicrobial activity of Nigella sativa L. seed oil against multi-drug resistant Staphylococcus aureus isolated from diabetic wounds. Pakistan journal of pharmaceutical sciences. 2015 Nov 1;28(6).

61. Chaieb K, Kouidhi B, Jrah H, Mahdouani $\mathrm{K}$, Bakhrouf A. Antibacterial activity of Thymoquinone, an active principle of Nigella sativa and its potency to prevent bacterial biofilm formation. BMC complementary and alternative medicine. 2011 Dec;11(1):1-6.

62. Salem EM, Yar T, Bamosa AO, Al-Quorain A, Yasawy MI, Alsulaiman RM, Randhawa MA. Comparative study of Nigella Sativa and triple therapy in eradication of Helicobacter Pylori in patients with nonulcer dyspepsia. Saudi journal of gastroenterology: official journal of the Saudi Gastroenterology Association. 2010 Jul;16(3):207.

63. Islam MH, Ahmad IZ, Salman MT. Antibacterial activity of Nigella sativa seed in various germination phases on clinical bacterial strains isolated from human patients. E3 Journal of Biotechnology and Pharmaceutical Research. 2013;4(1):8-13.

64. Barakat EM, El Wakeel LM, Hagag RS. Effects of Nigella sativa on outcome of hepatitis C in Egypt. World journal of gastroenterology: WJG. 2013 Apr 28;19(16):2529.

65. S. Gupta, M. Satishkumar, B. Duraiswamy et al., "Potential herbs and its phytoconstituents against fungal infection: a systematic review," World Journal of 
Pharmaceutical Research, vol. 1, pp. 1-20, 2012.

66. E. A. Rogozhin, Y. I. Oshchepkova, T. I. Odintsova et al., "Novel antifungal defensins from Nigella sativa L. seeds," Plant Physiology and Biochemistry, vol. 49, no. 2, pp. 131-137, 2011.

67. M. Suthar, P. Patel, T. Shah et al., "In vitro screening of Nigella sativa seeds for antifungal activity," International Research Journal of Pharmaceutical and Applied Sciences, vol. 1, no. 1, pp. 84-91, 2010.

68. H. Mahmoudvand, A. Sepahvand, S. Jahanbakhsh, B. Ezatpour, and S. A. A. Mousavi, "Evaluation of antifungal activities of the essential oil and various extracts of Nigella sativa and its main component, thymoquinone against pathogenic dermatophyte strains," Journal of Medical Mycology, vol. 24, no. 4, pp. e155-e161, 2014.

69. R. Khosravi, M. H. Minooeianhaghighi, H. Shokri, S. A. Emami, S. M. Alavi, and J. Asili, "The potential inhibitory effect of cuminum cyminum, ziziphora clinopodioides and nigella sativa essential oils on the growth of aspergillus fumigatus and aspergillus flavus," Brazilian Journal of Microbiology, vol. 42, no. 1, pp. 216-224, 2011.

70. Bita, A. Rosu, D. Calina et al., "An alternative treatment for Candida infections with Nigella sativa extracts," European Journal of Hospital Pharmacy: Science and Practice, vol. 19, no. 2, pp. 162.2-162, 2012.

71. Asdadi, H. Harhar, S. Gharby et al., "Chemical composition and antifungal activity of Nigella Sativa L. oil seed cultivated in Morocco," International Journal of Pharmaceutical Science Invention, vol. 3, pp. 9-15, 2014.

72. Piras, A. Rosa, B. Marongiu et al., "Chemical composition and in vitro bioactivity of the volatile and fixed oils of Nigella sativa L. extracted by supercritical carbon dioxide," Industrial Crops and Products, vol. 46, pp. 317-323, 2013.

73. S. Javed, A. A. Shahid, M. S. Haider et al., "Nutritional, phytochemical potential and pharmacological evaluation of Nigella Sativa (Kalonji) and Trachyspermum Ammi (Ajwain)," Journal of Medicinal Plants Research, vol. 6, no. 5, pp. 768-775, 201.
74. Tariq, M. 2008. Nigella sativa seeds: Folklore treatment in modern day medicine. Saudi J. Gastroenterol. 14: 105-106. 52.

75. Nadkarni, A. K. 1976. Indian materia medica. 3 rd ed. Mumbai: Popular Prakashan Pvt. Ltd. pp. 301-340. 53.

76. Warrier, P. K., Nambiar, V. P. K. and Ramankutty, C. 1996. Indian Medicinal Plants- A compendium of 500 species. Orient Longman Pvt. Ltd., Chennai 4: 139142. 54.

77. Sharma, Y., Bashir, S. Irshad, M., Gupta, S. D. and Dogra, T. D. 2005. Effects of acute dimethoate administration on antioxidant status of liver and brain of experimental rats. Toxicology 206: 49-57.

78. Boskabady MH, Javan H, Sajady M, Rakhshandeh $\mathrm{H}$. The possible prophylactic effect of Nigella sativa seed extract in asthmatic patients. Fundamental \& clinical pharmacology. 2007 Oct;21(5):559-66.

79. Ahmad A, Husain A, Mujeeb M, Khan SA, Najmi AK, Siddique NA, Damanhouri ZA, Anwar F. A review on therapeutic potential of Nigella sativa: A miracle herb. Asian Pacific journal of tropical biomedicine. 2013 May 1;3(5):337-52.

80. Tembhurne SV, Feroz S, More BH, Sakarkar DM. A review on therapeutic potential of Nigella sativa (kalonji) seeds. Journal of medicinal plants research. 2014 Jan 17;8(3):167-77.

81. G. O. Adam, M. M. Rahman, S.-J. Lee et al., "Hepatoprotective effects of Nigella sativa seed extract against acetaminophen induced oxidative stress," Asian Pacific Journal of Tropical Medicine, vol. 9, no. 3, pp. 221-227, 2016.

82. M. R. Mahmoud, H. S. El-Abhar, and S. Saleh, "The effect of Nigella sativa oil against the liver damage induced by Schistosoma mansoni infection in mice," Journal of Ethnopharmacology, vol. 79, no. 1, pp. 1-11, 2002.

83. F. Forouzanfar, B. S. Fazly Bazzaz, and H. Hosseinzadeh, "Black cumin (Nigella sativa) and its constituent (thymoquinone): A review on antimicrobial effects," Iranian Journal of Basic Medical Sciences, vol. 17, no. 12, pp. 929-938, 2014.

84. N. S. El Shenawy, M. F. M. Soliman, and S. I. Reyad, "The effect of antioxidant properties of aqueous garlic extract and Nigella sativa as anti-schistosomiasis agents in mice," Revista do Instituto de Medicina 
Tropical de Sao Paulo , vol. 50, no. 1, pp. 29-36, 2008.

85. E. I. Aboul-Ela, "Cytogenetic studies on Nigella sativa seeds extract and thymoquinone on mouse cells infected with schistosomiasis using karyotyping," Mutation Research - Genetic Toxicology and Environmental Mutagenesis, vol. 516, no. 1-2, pp. 11-17, 2002. [51]

86. M. Mohamed, N. M. Metwally, and S. S. Mahmoud, "Sativa seeds against Schistosoma mansoni different stages," Memorias ' do Instituto Oswaldo Cruz, vol. 100, no. 2, pp. 205-211, 2005.

87. Yaman, A. S. Durmus, S. Ceribasi, and M. Yaman, "Efects of Nigella sativa and silver sulfadiazine on burn wound healing in rats," Veterinarni Medicina, vol. 55, no. 12, pp. 619-624, 2010.

88. P. Sarkhail, H. Esmaily, A. Baghaei et al., "Burn healing potential of Nigella sativa seed oil in rats," International Journal of Pharmaceutical Sciences and Research, vol. 2, no. 1, pp. 34-40, 2011.

89. M. A. Abu-Al-Basal, "Influence of nigella sativa fixed oil on some blood parameters and histopathology of skin in staphylococcal-infected BalB/C mice," Pakistan Journal of Biological Sciences, vol. 14, no. 23, pp. 1038-1046, 20

90. M. R. Ab Rahman, F. Abdul Razak, and M. Mohd Bakri, "Evaluation of wound closure activity of nigella sativa, melastoma malabathricum, pluchea indica, and piper sarmentosum extracts on scratched monolayer of human gingival fibroblasts," Evidence-Based Complementary and Alternative Medicine, vol. 2014, Article ID 190342, 9 pages, 2014.

91. Dwarampudi LP, Palaniswamy D, Muruganantham Nithyanantham PS. Antipsoriatic activity and cytotoxicity of ethanolic extract of Nigella sativa seeds. Pharmacognosy magazine. 2012 Oct;8(32):268.

92. Ahmed Jawad H, Ibraheem Azhar Y, AlHamdi Khalil I. Evaluation of efficacy, safety and antioxidant effect of Nigella sativa in patients with psoriasis: A randomized clinical trial. J Clin Exp Invest www. jceionline. org Vol. 2014 Jun 1;5(2).

93. Hadi NA, Ashor AW. Nigella sativa oil lotion $20 \%$ vs. benzoyl peroxide lotion $5 \%$ in the treatment of mild to moderate acne vulgaris. Iraqi Postgraduate Medical Journal. 2010;9(4):371-6.

94. Ghorbanibirgani A, Khalili A, Rokhafrooz D. Comparing Nigella sativa oil and fish oil in treatment of vitiligo. Iranian Red Crescent Medical Journal. 2014 Jun;16(6).

95. Ali SA, Meitei KV. Nigella sativa seed extract and its bioactive compound thymoquinone: the new melanogens causing hyperpigmentation in the wall lizard melanophores. Journal of Pharmacy and Pharmacology. 2011 May;63(5):741-6.

96. Gholamnezhad Z, Keyhanmanesh R, Boskabady MH. Anti-inflammatory, antioxidant, and immunomodulatory aspects of Nigella sativa for its preventive and bronchodilatory effects on obstructive respiratory diseases: A review of basic and clinical evidence. Journal of Functional Foods. 2015 Aug 1;17:910-27.

97. Abedi AS, Rismanchi M, Shahdoostkhany M, Mohammadi A, Mortazavian AM. Microwave-assisted extraction of Nigella sativa L. essential oil and evaluation of its antioxidant activity. Journal of food science and technology. 2017 Nov;54(12):3779-90.

98. Kadam D, Lele SS. Extraction, characterization and bioactive properties of Nigella sativa seedcake. Journal of food science and technology. 2017 Nov;54(12):3936-47.

99. Fahmy HM, Saad EA, Sabra NM, ElGohary AA, Mohamed FF, Gaber MH. Treatment merits of Latanoprost/Thymoquinone-Encapsulated liposome for glaucomatus rabbits. International journal of pharmaceutics. 2018 Sep 5;548(1):597-608.ss

100. Cherif M, Valenti B, Abidi S, Luciano G, Mattioli S, Pauselli M, Bouzarraa I, Priolo A, Salem HB. Supplementation of Nigella sativa seeds to Barbarine lambs raised on low-or high-concentrate diets: Effects on meat fatty acid composition and oxidative stability. Meat science. 2018 May 1;139:134-41.

101. El-Najjar N, Chatila M, Moukadem H, Vuorela H, Ocker M, Gandesiri M, Schneider-Stock R, Gali-Muhtasib H. Reactive oxygen species mediate thymoquinone-induced apoptosis and activate ERK and JNK signaling. Apoptosis. 2010 Feb;15(2):183-95

102. Ishfaq PM, Shukla A, Beraiya S, Tripathi S, Mishra SK. Biochemical and 
pharmacological applications of essential oils in human health especially in cancer prevention. Anti-Cancer Agents in Medicinal Chemistry (Formerly Current Medicinal Chemistry-Anti-Cancer Agents). 2018 Oct 1;18(13):1815-27.

103. Aljabre SH, Alakloby OM, Randhawa MA. Dermatological effects of Nigella sativa. Journal of Dermatology \& Dermatologic Surgery. 2015 Jul 1;19(2):928.

104. Khalife R, Hodroj MH, Fakhoury R, Rizk S (2016) Thymoquinone from Nigella sativa seeds promotes the antitumor activity of noncytotoxic doses of topotecan in human colorectal cancer cells in vitro. Planta Med 82:312-321

105. Ahmad A, Husain A, Mujeeb M, Khan SA, Najmi AK, Siddique NA, Damanhouri ZA, Anwar F (2013) A review on therapeutic potential on Nigella sativa: a miracle herb. Asian Pac J Trop Biomed 3:337-352

106. Periasamy VS, Athinarayanan J, Alshatwi AA (2016) Anticancer activity of an ultrasonic nanoemulsion formulation of Nigella sativa L. essential oil on human breast cancer cells. Ultrason Sonochem 31:449-455

107. Al Asoom LI. Coronary angiogenic effect of long-term administration of Nigella sativa. BMC complementary and alternative medicine. 2017 Dec;17(1):1-7.

108. Czajkowska A, Gornowicz A, Pawłowska N, Czarnomysy R, Nazaruk J, Szymanowski W, Bielawska A, Bielawski K. Anticancer Effect of a Novel Octahydropyrazino $\quad\left[2, \quad 1-a: \quad 5, \quad 4-a^{\prime}\right]$ diisoquinoline Derivative and Its Synergistic Action with Nigella sativa in Human Gastric Cancer Cells. BioMed research international. 2017 Dec 26;2017.

109. Manjegowda SB, Rajagopal HM, Dharmesh SM. Polysaccharide of Black cumin (Nigella sativa) modulates molecular signaling cascade of gastric ulcer pathogenesis. International journal of biological macromolecules. 2017 Aug 1;101:823-36.

110. Mihoubi W, Sahli E, Gargouri A, Amiel C. FTIR spectroscopy of whole cells for the monitoring of yeast apoptosis mediated by p53 over-expression and its suppression by Nigella sativa extracts. PLoS One. 2017 Jul 12;12(7):e0180680.
111. Heshmati J, Namazi N. Effects of black seed (Nigella sativa) on metabolic parameters in diabetes mellitus: A systematic review. Complementary therapies in medicine. 2015 Apr 1;23(2): 275-82.

112. Sultan MT, Butt MS, Karim R, Ahmad AN, Suleria HA, Saddique MS. Toxicological and safety evaluation of Nigella sativa lipid and volatile fractions in streptozotocin induced diabetes mellitus. Asian Pacific Journal of Tropical Disease. 2014 Sep 1;4:S693-7.

113. Gray JP, Zayasbazan Burgos D, Yuan T, Seeram N, Rebar R, Follmer R, Heart EA. Thymoquinone, a bioactive component of Nigella sativa, normalizes insulin secretion from pancreatic $\beta$-cells under glucose overload via regulation of malonylCoA. American Journal of PhysiologyEndocrinology and Metabolism. 2016 Mar 15;310(6):E394-404.

114. El Rabey HA, Al-Seeni MN, Bakhashwain AS. The antidiabetic activity of Nigella sativa and propolis on streptozotocin-induced diabetes and diabetic nephropathy in male rats. Evidence-based Complementary and Alternative Medicine. 2017 Jan 1;2017.

115. Bensiameur-Touati K, Kacimi G, Haffaf EM, Berdja S, Aouichat-Bouguerra S. In vivo subacute toxicity and antidiabetic effect of aqueous extract of Nigella sativa. Evidence-Based Complementary and Alternative Medicine. 2017 Jan 1;2017.

116. Ahlatci A, Kuzhan A, Taysi S, Demirtas OC, Alkis HE, Tarakcioglu M, Demirci A, Caglayan D, Saricicek E, Cinar K. Radiation-modifying abilities of Nigella sativa and thymoquinone on radiationinduced nitrosative stress in the brain tissue. Phytomedicine. 2014 Apr 15;21(5):740-4.

117. Hobbenaghi R, Javanbakht J, Sadeghzadeh Sh, Kheradmand D, Abdi FS, Mohammadiyan MH, Jaberi MR, Mollaei FKY (2014) Neuroprotective efects of Nigella sativa extract on cell death in hippocampal neurons following experimental global cerebral ischemiareperfusion injury in rats. $\mathrm{J}$ Neurol Sci 337:74-79

118. Erboga M, Kanter M, Aktas C, Sener U, Erboga ZF, Donmez YB, Gurel A. Thymoquinone ameliorates cadmiuminduced nephrotoxicity, apoptosis, and 
oxidative stress in rats is based on its antiapoptotic and anti-oxidant properties. Biological trace element research. 2016 Mar 1;170(1):165-72.

119. Asif S, Malik L. Protective Effects of Nigella Sativa on Acetylsalicylic AcidInduced Nephrotoxicity in Albino Rats. J. Coll. Physicians Surg. Pak. 2017 Sep 1;27(9):536.

120. Sapmaz E, Sapmaz HI, Vardi N, Tas U, Sarsilmaz M, Toplu Y, Arici A, Uysal M. Harmful effects of formaldehyde and possible protective effect of Nigella sativa on the trachea of rats. Nigerian journal of clinical practice. 2017 May 24;20(5):523-9.

121. Kolahdooz M, Nasri S, Modarres SZ, Kianbakht S, Huseini HF. Effects of Nigella sativa L. seed oil on abnormal semen quality in infertile men: a randomized, doubleblind, placebo-controlled clinical trial. Phytomedicine. 2014 May 15;21(6):901-5.
122. Mahdavi R, Heshmati J, Namazi N. Effects of black seeds (Nigella sativa) on male infertility: A systematic review. Journal of Herbal Medicine. 2015 Sep 1;5(3):133-9.

123. Arif M, Thakur SC, Datta K. Implication of thymoquinone as a remedy for polycystic ovary in rat. Pharmaceutical biology. 2016 Apr 2;54(4):674-85.

124. Mosbah R, Djerrou Z, Mantovani A. Protective effect of Nigella sativa oil against acetamiprid induced reproductive toxicity in male rats. Drug and chemical toxicology. 2018 Apr 3;41(2):206-12.

How to cite this article: Thakur S, Kaurav H, Chaudhary G. Nigella sativa (kalonji): a black seed of miracle. International Journal of Research and Review. 2021; 8(4): 342-357. DOI: https://doi.org/10.52403/ijrr.20210441 